\title{
Consequentialism about Meaning in Life
}

\author{
Ben Bramble \\ University of Vienna
}

\section{INTRODUCTION}

What is it for a life to be meaningful? Let us start by getting clear on the topic. Susan Wolf picks it out well, in two distinct ways. First, by reference to familiar needs or longings (and corresponding crises). Wolf writes:

A meaningful life is, first of all, one that has within it the basis for an affirmative answer to the needs or longings that are characteristically described as needs for meaning. I have in mind, for example, the sort of questions people ask on their deathbeds, or simply in contemplation of their eventual deaths, about whether their lives have been (or are) worth living, whether they have had any point, and the sort of questions one asks when considering suicide and wondering whether one has any reason to go on. ${ }^{1}$

The idea is that we can get a handle on the notion of meaning in life by reflecting on what it is we are wondering whether our lives have (or lamenting that they lack) at times such as these. Meaning, whatever it is, is the sort of thing that should have a tendency to put these longings or crises to rest were we to apprehend it clearly.

Second, by reference to paradigms of meaningful and meaningless lives. Wolf writes:

Lives of great moral or intellectual accomplishment - Gandhi, Mother Teresa, Albert Einstein - come to mind as unquestionably meaningful lives (if any are); lives of waste and isolation - Thoreau's "lives of quiet desperation," typically anonymous to the rest of us, and the mythical figure of Sisyphus [condemned to roll a rock up a hill for eternity] - represent meaninglessness. ${ }^{2}$

Having cleared up the topic, let us now turn to theories of meaning in life. The most influential contemporary theory is Wolf's own Fitting Fulfillment View. ${ }^{3}$ According to this view, there are two necessary and jointly sufficient conditions of meaning in life. First,

\footnotetext{
${ }^{1}$ Susan Wolf, 'Happiness and Meaning: Two Aspects of the Good Life', Social Philosophy \&? Policy 14 (1997), pp. 207-225, at 208.

${ }^{2}$ Wolf, 'Happiness and Meaning', p. 209.

${ }^{3}$ This is the name Wolf gives her view in her book-length treatment of the topic, Meaning in Life and Why It Matters (Princeton, 2010).
} 
that one be passionate about, or love, something one is doing. (The Passion Requirement.)

One must, that is, be "gripped or excited"4 by the activity in question, as opposed to being "bored or alienated" 5 by everything about it. Being gripped or excited by something one is doing, in turn, Wolf tells us, involves having "good feelings", but does not guarantee being happy. ${ }^{6}$ Second,

that the activity in question is objectively good. (The Objectivity Requirement.)

The activity, that is, must have a value that is "independent of and has its source outside of oneself", or, in other words, a value that "does not depend on one's own contingent interest in [it]". ${ }^{7}$ It must be good in some way other than being good for oneself.

Wolf nicely sums up her view in the following slogan:

Meaning arises when subjective attraction meets objective attractiveness. ${ }^{8}$

In this paper, I will argue that both of Wolf's requirements are mistaken. On the theory I will defend, Consequentialism about Meaning in Life (or CML for short),

(1) one's life is meaningful at time $t$ just in case one's surviving at $t$ would be good in some way (either subjectively or objectively),

and

(2) one's life was meaningful considered as a whole just in case the world was (or will be) made better in some way for one's having existed.

In Section II, I will argue that passion is not necessary for meaning in life, because an ability to contribute to objectively good things is sufficient for it. ${ }^{9}$ In Section III, I will argue that an ability to contribute to subjectively good things (i.e., things whose value depends on one's own contingent interest in them) is also sufficient for one's life to be meaningful at a time.

\section{THE PASSION REQUIREMENT}

I will first respond to three arguments for the passion requirement. I will then provide three objections to it.

\footnotetext{
${ }^{4}$ Wolf, Meaning in Life, p. 14.

${ }^{5}$ Wolf, 'Happiness and Meaning', p. 211.

${ }^{6}$ Wolf, Meaning in Life, p. 14.

${ }^{7}$ Wolf, Meaning in Life, p. 19.

${ }^{8}$ Wolf, Meaning in Life, p. 26.

${ }^{9}$ When I refer to an ability to contribute to good things, I mean just that one's surviving would have good consequences. What matters for the meaningfulness of my life now, according to CML, is how the world would go were I to survive, not how it might go. If, were I to survive, I would give none of my spare millions to Oxfam, my 'ability' to do so contributes nothing to my life's being meaningful now.
} 


\section{Sisyphus Who Scares Away Vultures}

Consider, says Wolf, a modified version of Sisyphus, whose rock rolling, unbeknownst to him, "scares away vultures who would otherwise attack a nearby community and spread terror and disease" 10 . Such a Sisyphus is contributing to objectively good things, but his life nonetheless seems completely meaningless.

But his life does not seem completely meaningless to me! Indeed, it seems to have a great deal of meaning owing to its good consequences for the villagers. Suppose this Sisyphus, in the grip of a crisis of meaning, were about to throw himself off the mountain, but we had one last chance to communicate with him. Here's what I would say: "Wait, Sisyphus! Don't do it! You don't realise it, but your rock rolling is averting a great deal of suffering. It's scaring off vultures that would otherwise attack nearby villagers and spread disease." This seems like a perfectly appropriate thing to say, and its clear implication is that his life has meaning - meaning that he hasn't been aware of. In telling him about the vultures, I'd be helping him to discover some meaning that his life already has.

But if Wolf were right that passion is necessary for meaning, then there would be no positive news to give Sisyphus. If he were to look to the heavens and cry, "O ye gods, what reason have I to live?", we ought to remain silent. He has no passion for anything he is doing, and so, on Wolf's view, no reason to go on living. This, it seems to me, is highly implausible. ${ }^{11}$ Indeed, it is obvious - isn't it? - that depressed people can be wrong that their lives are meaningless. If Wolf's view were correct, then any passionless person who wonders whether his life has any meaning is conceptually confused - if he knew what meaningfulness required, he would know that it didn't have any! We can put the point in a slightly different way: A depressed person already knows he is depressed, he is wondering precisely whether he is right to feel this way.

Undoubtedly, passion is important in our lives, and we often yearn for it if we have none. Indeed, as I will be arguing in Section III, there is something similar to passion that suffices for meaning at a time. But it is a mistake to think that just because somebody is yearning for passion he is yearning for meaning. He may yearn for passion, while being in no doubt of the meaningfulness of his life. Consider

The Master Economist. Alice spends her days managing the economy, something only she (given her talents) can do. She finds it utter drudgery, but knows she must continue because of all the good she is doing.

Alice may yearn for passion in her life, while having no doubt - not for one minute of its considerable meaningfulness.

Related to this, it is vital not to confuse one's life's being meaningful with one's having a sense of meaning in one's life. Whatever exactly the latter involves (whether it is simply a belief that one's life has meaning, or such a belief combined with a certain kind of positive feeling) one can surely have it without having any actual meaning in one's life. ${ }^{12}$

${ }^{10}$ Wolf, Meaning in Life, p. 21.

${ }^{11}$ For a similar example, see Hooker's professor who is an inspirational teacher, but has no passion for teaching, in Brad Hooker, 'The Meaningful Life: Subjectivism, Objectivism, and Divine Support', in Nafsika Athanassoulis and Samantha Vice (eds), Morality and the Good Life: Essays in Honour of Fohn Cottingham (2008), pp. 184-200, at 193.

${ }^{12}$ For more on this distinction, see Hooker, 'The Meaningful Life', p. 192. 
R. W. Hepburn writes:

To give life meaning cannot be just a matter of pursuing worthy projects, for that account fails to cope with phenomena like Tolstoy's arrest of life, or John Stuart Mill's during his mental crisis of $1826 .{ }^{13}$

Hepburn's worry is that, if making a contribution to objectively good things were sufficient for meaning in life, then it would be inexplicable how Tolstoy and Mill, who surely could not have doubted the worth of their projects, suffered crises.

However, the memoirs of both Tolstoy and Mill reveal that they suffered their respective crises only after doubting the value or worth of their projects. In $A$ Confession, Tolstoy writes

Amidst my thoughts of farming, which interested me very much during that time, there would suddenly pass through my head a question like this: "All right, you are going to have six thousand desyatinas of land in the Government of Samara, and three hundred horses, - and then?" And I completely lost my senses and did not know what to think farther. Or, when I thought of the education of my children, I said to myself: "Why?" Or, reflecting on the manner in which the masses might obtain their welfare, I suddenly said to myself: "What is that to me?" Or, thinking of the fame which my works would get me, I said to myself: "All right, you will be more famous than Gogol, Pushkin, Shakespeare, Moliere, and all the writers in the world, - what of it?" And I was absolutely unable to make any reply. The questions were not waiting, and I had to answer them at once; if I did not answer them, I could not live. ${ }^{14}$

Here, Tolstoy seems to be attributing his crisis of meaning to doubts about the worth of his farming, his children's education, his writing, and the welfare of the masses for which he had been striving for so long.

What led him to doubt the worth of these things? He says it was thoughts of mortality (both his own and others). He writes:

Sooner or later there would come diseases and death (they had come already) to my dear ones and to me, and there would be nothing left but stench and worms. All my affairs, no matter what they might be, would sooner or later be forgotten, and I myself should not exist. So why should I worry about all these things? ${ }^{15}$

In Tolstoy's case, then, it seems that thoughts of mortality led him to question the worth of his activities, which, in turn, gave rise to his crisis of meaning. Only then did he lose passion for his activities. He is, then, properly understood, a counterexample to the views of Hepburn and Wolf.

\footnotetext{
${ }^{13}$ R. W. Hepburn, 'Questions About the Meaning of Life', in The Meaning of Life, edited by E.

D. Klemke (Oxford, 1981), p. 212.

${ }^{14}$ Leo Tolstoy, A Confession, translated by Leo Wierner (1905).

15 Tolstoy, A Confession.
} 
As for Mill, he explicitly put his crisis down to a feeling that the end to which he was devoting his life, the progress of humanity, was worthless. He writes:

The end had ceased to charm, and how could there ever again be any interest in the means? I seemed to have nothing left to live for...[The] destiny of mankind in general was ever in my thoughts...I felt that unless I could see my way to some better hope than this for human happiness in general, my dejection must continue. ${ }^{16}$

Mill, it is true, lost all passion for his activities. But this occurred only after and because he came to doubt the worth or point of them.

\section{The Result Machine}

Thaddeus Metz asks us to consider a thought experiment of Robert Nozick's, The Result Machine, which can be programmed to bring about any outcome whatever. If a consequentialist theory (like GML) were true, Metz says,

then a maximally meaningful life would be one that programmed the machine, or pushed the relevant buttons, so as to bring about as much objective value as it could. ${ }^{17}$

However, he claims,

That judgment is counterintuitive. Even if it were the case that one ought to get the machine running, one's life would not be maximally meaningful for having done so. Instead, a fully meaningful life, insofar as it involves the promotion of objective value, requires effortful or hands on activity. ${ }^{18}$

He then offers a similar case of his own:

Less fantastically, merely cutting a check to Oxfam, donating funds that one was lucky to inherit, would not be as meaningful as laboring in the poor community that Oxfam seeks to benefit, supposing the latter produced only marginally fewer objectively good long-term outcomes than the former. However, [consequentialism] cannot account for that intuition, since the nature of the means by which the objective value is brought about does not matter... [The] more that is brought about by whatever...mechanism, the more meaningful one's life. ${ }^{19}$

It is essential, however, to distinguish between two ways in which a person can be said to do something good. Suppose you are at the beach when you see a child drowning in shallow water. You wade in and lift her out, saving her life. Had you not done so, your friend Mary would have done so instead (at no cost to Mary or anyone else). Here,

\footnotetext{
${ }^{16}$ John Stuart Mill. Autobiography (1873).

17 Thaddeus Metz, Meaning in Life: An Analytic Study (Oxford, 2013), p. 194.

${ }^{18}$ Metz, Meaning in Life, p. 194.

${ }^{19}$ Metz, Meaning in Life, p. 195.
} 
there is a sense in which you have done something good. It is good that the child was saved, and you are the one who saved her. But there is also a sense in which you did not do anything good, for had you not waded into the water, the world would be no worse a place. ${ }^{20}$

CML, as I intend it, says only that it is when one would, by surviving, make a contribution to good things that would not otherwise be made that one's life is meaningful now. Hence, according to GML, my ability to press Nozick's button confers meaning on my life now only if, were I not to press it, it would not get pressed (or if, were somebody else to press it, there would be some cost associated with that). If my friend Mary were standing by, ready to press the button if I did not, or someone else would be offered the chance to do so, and at no cost to anybody, then my ability to press it, according to GML, does not confer meaning on my life now. Perhaps what is leading Metz to think that my ability to press the button does not make my life maximally meaningful now is that he is assuming that the button is easy to press, so that if I did not press it somebody else would.

It is for a similar reason that another of Wolf's arguments for the passion requirement, her 'bored assembly line worker'21, fails. According to Wolf, if an ability to contribute to objectively good things were sufficient for meaning in life, then the work of such an assembly line worker would have to add at least some meaning to her life. But clearly it does not - her life may be utterly meaningless.

But assembly line work, very often, does not require a lot of skill or training, and so one may be easily replaced in it. If there were many unemployed people looking for work, then Wolf's assembly line worker may not have an ability to contribute to anything good in the relevant (Robust) sense, for she may not be making a contribution to good things that would not otherwise be made. Of course, if she were using her income to feed her family, who would not otherwise be fed, then CML does entail that her work adds meaning to life - but this seems exactly right.

This distinction between two ways in which a person might do good things is central to the right account of why our relationships are so important a source of meaning in our lives. The contribution we make to the lives of those who love us - in certain cases simply by our continuing to exist (for example, in the case of a severely handicapped person or a bedridden grandmother) - is one that cannot be made by anyone else. For example, the quality of the pleasures that our company affords those who love us is unique - these pleasures could not be provided by anyone else. ${ }^{22}$

Here is an additional suggestion for what is confusing philosophers like Metz. According to CML, while my ability to press Nozick's button (assuming that it would not otherwise be pressed) confers a great deal of meaning on my life as it is now (i.e., adds a great deal to the present momentary meaningfulness of my life), my actually pressing $i t$, if this would result in there being nothing more that I could ever do to contribute to good things, would mean that, once I had pressed it, my life could never again be momentarily meaningful in the slightest. Similarly, while my ability to write the cheque to Oxfam, and my ability to go work as a laborer in the poor community, may confer roughly equal amounts of meaning on my life as it is now, my actually

${ }^{20}$ Wolf draws a similar distinction between what she calls the Ordinary Sense and the Robust Sense of 'good for' in her piece 'Good-for-Nothings', Proceedings and Addresses of the American Philosophical Association, 85 (2012).

${ }^{21}$ Wolf, Meaning in Life, p. 21.

${ }^{22}$ A similar point is made by Antti Kauppinen in his excellent 'Meaningfulness and Time', Philosophy and Phenomenological Research, 84 (2012), pp. 345-377, at 364. 
going to work there as a laborer would make my life momentarily meaningful for longer, because, were I to do that, I would, at each new moment, be continuing to be a source of good things in the world.

Of course, it is perfectly true that, according to GML, my writing the check to Oxfam, if it is for a sufficiently large amount, may do more to make my life meaningful considered as a whole than would my going to work in the poor community. Some may find this hard to accept. I must admit, though, that I do not. It seems plausible to me that the ultra wealthy have an opportunity to add meaning to their lives that the vast majority of us lack. This, of course, it must be emphasised, does not mean that the ultra wealthy have an opportunity to be either better people or better off than the rest of us. A person's moral worth is not plausibly determined by her actual contributions, but only by those she would make if given the chance. And meaning in life is not intrinsically good for one. It does not belong on a so-called 'objective list' theory of welfare.

Finally, suppose an ability to contribute to subjectively good things is also sufficient for one's life to be meaningful at a time (a claim I will be arguing for in Section III). In this case, my going to work in the poor community would very likely provide me with a kind or source of meaning that no amount of cheque-writing could possibly provide. This is because it - unlike cheque-writing - would, in all likelihood, be a life-changing and fulfilling experience for me.

\section{The Paradigms}

Recall the paradigms of meaningful lives: Gandhi's, Mother Teresa's, Einstein's, etc. What is distinctive about these? It seems to be nothing other than the enormity of their contributions to society.

To see that this is so, consider that most of us have no idea whether these individuals were fulfilled in their lives, whether they had any passion for their activities. Most of us know only of their great contributions. Suppose we discovered that Einstein thought about mathematics only to silence voices in his head that were preventing him from getting to sleep at night, and that he had no passion for anything in his life, let alone solving those blasted math problems. Would we cease to think of his life as a paradigm of meaningfulness, and instead come to regard it as having been completely meaningless? Of course not! If an Einstein like this were to walk up to us and complain that his life was meaningless, that there was no point to it, etc., it would seem perfectly appropriate for us to insist he was mistaken, and to try to show him all the good his ideas were doing. ${ }^{23}$

\section{Ambiguity of "A Life Worth Living"}

As Wolf says, a meaningful life is one that is 'worth living'. However, there is an important ambiguity in the phrase 'a life worth living' that I suspect is confusing some philosophers who believe that passion is necessary for meaning in life.

\footnotetext{
${ }^{23}$ What if Einstein's ideas ended up doing more harm than good (say, by making possible nuclear weapons)? Would we still want to say that his life was paradigmatically meaningful, or even meaningful at all? For some interesting recent work on this topic, see Stephen Campbell $\&$ Sven Nyholm, 'Anti-Meaning and Why It Matters' (unpublished manuscript).
} 
In one sense, a life is worth living if and only if its subject has a self-interested reason to go on living it - i.e., just in case it is a life that is worth living for her. For this to be so, some passion for one's activities is arguably required. However, there seems also to be a sense in which one's life can be worth living even if one lacks a self-interested reason to go on living it - even, that is, if it is not worth living for one. It is worth living in this latter sense just in case one is contributing (in a Robust way) to good things. It is a life worth living in this latter sense, I would suggest, that is equivalent to what we are engaged in investigating in the literature on meaning in life. Consider, once again, crises of meaning. We may, it seems, coherently wonder whether our life is worth living, even if we know that it is not worth living for us.

Finally, it is worth noting that it is plausible that some of us must have lives that are worth living for ourselves if any of us is to have a life worth living solely in virtue of his contributions to objectively good things. This is because, if no lives were worth living for their subjects, then (on the plausible assumption of welfarism about value - more on this in Section III) there could be nothing of value in the universe, and so no way that any one of us could contribute to anything objectively good.

\section{It's A Wonderful Life}

Consider George Bailey in the film It's A Wonderful Life. ${ }^{24}$ When George discovers he has been framed for fraud and is soon to be arrested, he is so despondent that he goes to the town bridge to throw himself off it. He is saved by Clarence, his guardian angel, who takes him on a tour of Bedford Falls (now 'Pottersville', after the nefarious Mr. Potter) as it would have been had he, George, never existed. Everyone is much worse off. His mother is a bitter landlady. His friends (the local bartender and policeman) are ungenerous, unhappy people. The local pharmacist, whom George had prevented from accidentally poisoning a child, is in prison. George's younger brother, having not been saved from drowning by George when they were children, did not go on to become a war hero, and so did not himself save countless lives. Worst of all, George's beloved Mary is a dejected spinster. Seeing all this restores George's will to live, and he is returned to reality, whereupon he dashes home to be reunited with his family.

What is Clarence trying to get George to realise by showing him Pottersville? A natural answer is the meaningfulness of his life. What Clarence shows George, however, is strictly his contributions to the lives of others. At no point does George's mind turn to any passion he has had for his own activities. Indeed, it is doubtful whether George has ever had much passion for his own activities - he is depicted as having yearned, his whole life, to get out of Bedford Falls. In any case, the thoughts responsible for reigniting George's will to live, his sense that his life has meaning, are only of his importance to the lives of his friends and family.

\section{THE OBJECTIVITY REQUIREMENT}

I will first respond to Wolf's main argument for the objectivity requirement. I will then provide a counterexample to the requirement.

\section{Sisyphus Fulfilled}

${ }^{24}$ This example has been suggested independently by Aaron Smuts in his paper 'It's a Wonderful Life: Pottersville and the Meaning of Life', Film and Philosophy, 16 (2012), pp. 15-33. 
Wolf asks us to consider

a person who simply loves smoking pot all day, and another (or maybe the same person) who is fulfilled doing crossword puzzles, or worse (as personal experience will attest), Sudokus. We might also consider more bizarre cases: a man who lives to make handwritten copies of the text of War and Peace; or a woman whose world revolves around her love for her pet goldfish...[Consider also] Sisyphus Fulfilled...who loves stone-rolling more than anything else in the (after-)world. ${ }^{25}$

Not only are these people passionate about their activities, Wolf says, their activities are subjectively good (i.e., good in virtue of being good for them). But these activities clearly add nothing in the way of meaning to their lives. The upshot, Wolf thinks, is that activities need to be objectively good if they are to add meaning to one's life.

I agree with Wolf that the activities of these people may add nothing to meaning in their lives. But I think she is mistaken that these activities are subjectively good. Why is this? It is because for something to be good in virtue of being good for someone, it must add to this person's lifetime welfare, and the activities in Wolf's examples, while they may increase their subjects' momentary welfare at the time of experience, add nothing to these people's lifetime welfare.

I will not here defend the claim that for something to be good in virtue of being good for someone, it must add to this person's lifetime welfare. ${ }^{26}$ But I do want to say something in defense of the idea that the activities in Wolf's examples add nothing to these people's lifetime welfare. The reason they add nothing, I believe, is that what they provide is 'just more of the same'. The right theory of lifetime welfare (whether it is a hedonistic, desire-satisfactionist, or pluralistic one) should say that having more of exactly the same kind of momentary benefit adds nothing in and of itself to lifetime welfare (though it may, of course, add instrumentally, by, say, improving one's ability to think clearly or function well). It is only new kinds of momentary benefits - for example, qualitatively new pleasures, new kinds of aesthetic experiences, different or deeper insights into the nature of things, etc. - that in and of themselves can add anything to lifetime welfare. Smoking more pot, making more copies of War and Peace, rolling more rocks, etc., adds nothing in and of itself.

This seems to be why thoughts concerning the cyclical nature of our lives can so easily induce crises of meaning. Consider Joel Feinberg's description of the thoughts that led him to suffer crises of meaning while watching shoppers go about their business in a bustling marketplace:

Why are all those people standing in line before the cash registers? In order to purchase food. Why do they purchase food? In order to stay alive and healthy. Why do they wish to stay alive and healthy? So that they can work at their jobs. Why do they want to work? To earn money. Why do they want to earn money? So they can purchase food. And so on, around the circle, over and over, with no 'significant culmination' in sight. ${ }^{27}$

\footnotetext{
${ }^{25}$ Wolf, Meaning in Life, p. 16.

${ }^{26}$ For a defense of this claim, see Ben Bramble, 'Whole-Life Welfarism', American Philosophical Quarterly, 51 (2014), pp. 63-74.

${ }^{27}$ Joel Feinberg, Freedom and Fulfillment (1992), p. 308.
} 
It is, I believe, not the lack of a significant culmination per se that can make us feel that these people's lives are meaningless, but the fact that their activities are 'just more of the same'. They seem, for this reason, to add nothing to these people's lifetime welfare, and so to be of no positive value.

Richard Taylor, also, writes:

We toil after goals, most of them - indeed, every single one of them - of transitory significance and, having gained one of them, we immediately set forth for the next, as if that one had never been, with this next one being essentially more of the same. Look at a busy street any day, and observe the throng going hither and thither. To what? Some office or shop, where the same things will be done today as were done yesterday, and are done now so they may be repeated tomorrow...Most such effort is directed only to the establishment and perpetuation of home and family; that is, to the begetting of others who will follow in our steps to do more of the same. ${ }^{28}$

If I am right, these thoughts are apt to induce crises of meaning because they depict us as living in such a way that we are not becoming any better off in our lives considered as a whole, and so as contributing to nothing of value.

This account also explains what is missing in some other famously meaningless lives - for example, those of David Wiggins' Hog Farmer (who "grows more corn to feed more hogs to buy more land to grow more corn to feed more hogs" 29 ), Wolf's Blob (who "spends day after day, or night after night, in front of a television set, drinking beer and watching situation comedies"), as well as her Idle Aristocrat (who "flits about, fighting off boredom, moving from one amusement to another") ${ }^{30}$. Consider also the lives of Taylor's Glow Worms:

This goes on month after month, the blind worm lying there in the barren stillness waiting to entrap an occasional bit of nourishment that will only sustain it to another bit of nourishment until...Until what? What great thing awaits all this long and repetitious effort and makes it worthwhile? Really nothing. The larva just transforms itself finally to a tiny winged adult that lacks even mouth parts to feed and lives only a day or two. These adults, as soon as they have mated and laid eggs, are themselves caught in the threads and are devoured by the cannibalist worms, often without having ventured into the day, the only point to their existence having now been fulfilled. This has been going on for millions of years, and to no end other than that the same meaningless cycle may continue for another millions of years. ${ }^{31}$

Finally, consider the young mother discussed in Betty Friedan's book The Feminine Mystique, who tries to account for her feeling of ennui as follows:

\footnotetext{
${ }^{28}$ Richard Taylor, 'The Meaning of Life', in Life, Death, and Meaning, edited by David Benatar (2010), p. 26.

${ }^{29}$ David Wiggins. 'Truth, Invention, and the Meaning of Life', Proceedings of the British Academy 62 (1976), p. 332-378.

30 These cases are from Susan Wolf, 'The Meanings of Lives', in Perry, Bratman, Fischer, eds., Introduction to Philosophy: Classical and Contemporary Readings (2007).

31 Taylor, 'The Meaning of Life', p. 25.
} 
I ask myself why I am so dissatisfied. I've got my health, fine children, a lovely new home, enough money...It's as if ever since you were a little girl, there's always been somebody or something that will take care of your life: your parents, or college or falling in love, or having a child, or moving to a new house. Then you wake up one morning and there's nothing to look forward to ${ }^{32}$

In discussing her case, Peter Singer notes that it was mainly women who experienced such a loss of purpose in the fifties, because

most men, but relatively few women, worked in jobs that held out the prospect of a promotion, an increase in responsibility and power...So when one morning a man wakes up and asks himself, 'Is this all there is to my life?' he can quieten the doubts by thinking about that coming glorious day when he gets to move up to a more important position, with higher pay and more responsibility. That is why, as both employers and unions have found, a career structure, a ladder leading upwards, is often more crucial for job satisfaction than actual rates of pay. In contrast, for a housewife there is no promotion. Romance will fade, and the children will need their mother less and less. ${ }^{33}$

For all these individuals, there is (as far as they can see) nothing new on the horizon. If I am right, this means that (once again, from their persective) there is no further increase possible in their own levels of lifetime welfare, and so nothing even subjectively good that depends on their own continued existence.

I conclude that Wolf's argument does not establish that one's activities need to be objectively good if they are to add meaning to one's life. While it is true that the activities she mentions probably add nothing in and of themselves to meaning in their subjects' lives, they are not, as Wolf claims, subjectively good.

\section{The Shipwrecked Botanist}

I want now to provide an example of a life that is only subjectively good, but seems meaningful nonetheless. Consider

The Shipwrecked Botanist. A botanist has been shipwrecked alone on a desert island with all of his books and instruments. He cannot believe his luck! Finally, he has an opportunity to fulfill his long-held ambition of studying exotic desert island flora.

We might add that he is a talented artist, with a keen interest in tropical landscapes, and has been shipwrecked along with all of his painting supplies.

Could the life of this botanist be meaningful on the island? Certainly, it could be. Indeed, it is tempting to think that it could be far more meaningful there than back in his homeland - especially if we assume that he loathed his day job, had little spare time to pursue his passions, and had no especially close friends or family. But the moment he washed up on this island was exactly the moment at which his life ceased to be objectively valuable, for he is all alone on this island. (Assume that he will never

\footnotetext{
${ }^{32}$ Quoted in Peter Singer, How Are We To Live? (1995), p. 211. My emphasis.

${ }^{33}$ Singer, How Are We To Live?, p. 211.
} 
be discovered or have any effect whatsoever ever again on the lives of others.)

I am here assuming welfarism about value, the view that something can be good only by being good for some being or beings. Wolf may reject this assumption. Indeed, she writes (though not in response to the sort of objection I have raised here):

Creating art, adding to our knowledge of the world,...seem intuitively to deserve classification as valuable activities, even if they do not bring about obvious improvement in human or animal welfare. ${ }^{34}$

Similarly, the mere "exercise of virtue and talent - of intellectual creativity and integrity, of patience, discipline, and determination - has value in itself". ${ }^{35}$

If Wolf were right that such things are valuable independently of their contribution to people's welfare, then the shipwrecked botanist could, even on her Fitting Fulfillment View, have a meaningful life on the island. But it is very hard to believe that these things are objectively valuable. What is the point of making beautiful objects, gaining knowledge of the world, or developing skills, if nobody - not even oneself - will benefit from these things? Intuitively, it would be better to confer even the smallest benefit upon somebody than to do any of these things. ${ }^{36}$

\section{Lifetime Meaningfulness}

Before concluding, I wish to make one final point. If CML is true, then it may be that one's life can be meaningful considered as a whole only if one contributes to objectively good things. Why is this? According to CML, a person's life was meaningful considered as a whole just in case the world was (or will be) made better in some way as a result of this person's having existed. But there is reason to think that one's having existed can be good only objectively. It cannot be subjectively good, because it cannot be good for oneself. Why can't it be good for oneself? Here's why:

(1) Something is good for a person only if it makes him better off in some way than he would otherwise have been.

(2) Had a person not existed, then he would not have been, and so would not have had a level of welfare.

Therefore,

(3) One's having existed cannot make one better off than one would otherwise have been.

Therefore,

\footnotetext{
${ }^{34}$ Wolf, Meaning in Life, p. 37.

${ }^{35}$ Wolf, Meaning in Life, p. 106.

${ }^{36}$ It is beyond the scope of this essay to give a full defense of welfarism. For more on welfarism, see Bramble (2014) and Roger Crisp \& Andrew Moore, 'Welfarism in moral theory', Australasian Fournal of Philosophy 74 (1996), pp. 598-613. Note that, while welfarism provides support for CML, CML neither entails nor relies on welfarism.
} 
(4) One's having existed cannot be good for oneself. ${ }^{37}$

Suppose this is right. Perhaps it is a failure to distinguish between one's life's being meaningful at a time and one's having had a meaningful life considered as a whole that explains why some philosophers are tempted to think that meaning at a time requires an ability to contribute to objectively good things.

\section{GONGLUSION}

I want to conclude with a clear statement of why, if CML is true, almost every human life is somewhat meaningful, both at most times and considered as a whole. It is because (1) for the vast majority of us, continuing to exist at any given time would result in our becoming better off in some way in our life considered as a whole, or at least in one of our friends or loved ones becoming better off in some way in his life considered as a whole, and (2) most of us will make, during the course of our lives, at least one person besides ourselves better off in some way in his life considered as a whole. $^{38}$

b.e.bramble@gmail.com

${ }^{37}$ Something like this argument has been suggested by many philosophers. See, for example, John Broome, Ethics Out Of Economics (Cambridge, 1999), p. 168. Note that an advocate of GML needn't accept this argument, and is not committed to (4).

38 This paper was funded by the ERG-Advanced Research Grant "Distortions of Normativity". 